\title{
Vegetation Distribution in BadLANDS NATional PARK
}

\author{
JACK L. Butler ^ JAMES E. BATt \\ Department of Biology $\downarrow$ University of SOUth Dakota \\ VERMILLION
}

During the course of the 1990 field season a total of 143 sites were sampled, primarily within the Sage Creek Wilderness Area. Specific study sites were selected with use of soil survey photo-orthoquad maps. Once located, the vegetation which best represented the plant community residing on that soil type was selected for detailed study using the cover class system as described by Daubenmire (1959). The data collected during the 1990 field season is currently undergoing compilation in preparation for statistical analysis. No major problems were encountered during the field season which will limit our ability to meet project objectives.

\section{$\downarrow$ Executive Summary}

The rather steep environmental gradients associated with badlands-type topography often produces an intricate mosaic of distinct vegetation types (Brown 1971, Butler et al. 1984, Hansen et al. 1984, Olson 1988). Detailed ecological descriptions of these complex communities is essential for the management and perpetuation of such a diverse ecosystem. In 1988, a study was initiated to delineate the vegetation types within Badlands National Park, South Dakota, and to evaluate their current and potential ecological condition. Specific objectives of this study are to:
1. to determine the steppe habitat types and indicate the seral stages of the current vegetation;

2. to provide a mylar map of climax/relict communities, if any, for the entire park;

3. to establish a network of permanent plots to evaluate changes in seral and climax communities for the North Unit and Sheep Mountain Table; and

4. to provide a mylar map of candidate and/or listed rare, threatened, or endangered plant species per state and federal lists, as they are encountered during the course of the study.

In 1988, Hoffman (1989) tentatively identified seven habitat types. They are

1. Agropyron smithii/Carex filifolia,

2. Agropyron smithii/Carex eleocharis,

3. Stipa comata/Agropyron smithii,

4. Stipa viridula/Agropyron smithii,

5. Stipa comata/Carex eleocharis,

6. Stipa comata/Carex filifolia,

7. Calmovilfa longifolia/Agropyron smithii.

The 1990 field season began with an initial reconnaissance of the North Unit of the Park and a meeting with Badlands National Park staff.

The preliminary reconnaissance was followed by two, three-week periods of intensive sampling in conjunction with ongoing reconnaissance. These 
three-week periods ran from about June 8 to June 28 , and from July 10 to August 1 . During the first threeweek sampling period, Dr. Fred Peabody, Curator of the University of South Dakota Herbarium and Assistant Professor of Biology spent some time reviewing the park herbarium. Dr. Peabody also collected plant specimens to update the park herbarium. The 1990 field season ended with a final visit to the Badlands National Park in mid-August to fill in several gaps in the field work and to brief park personnel as to the progress made during the current field season.

During the course of the 1990 field season, a total of 143 sites were sampled, primarily within the Sage Creek Wilderness Area. Specific study sites were selected with use of soil survey photo-orthoquad maps obtained from the Soil Conservation Service office located in Huron, SD. Once located, the vegetation which best represented the plant community residing on that soil type was selected for detailed study. The representative vegetation was taken to be that which was homogeneous in composition and free from animal trails, badlands formations, and other major breaks in topography. In some cases, a particular habitat type required several sampling sites to adequately describe the vegetation mosaic. In small areas where the vegetation pattern was extremely complex, the community was described qualitatively. Two, parallel $25 \mathrm{~m}$ transects running along the contour of the topography were established at each site. A 20 $X 50 \mathrm{~cm}$ quadrat was placed on alternate sides of each transect at $1 \mathrm{~m}$ intervals for a total of 50 quadrats per sample site. Within each quadrat, each plant species was identified and placed in a cover class as described by Daubenmire (1959). Bare ground and litter present in each quadrat were placed in a single cover class.

The data collected during the 1990 field season is currently undergoing compilation in preparation for statistical analysis. Cover values will be averaged for site characterization and description, and to evaluate sampling adequacy for the major species. However, averaging the values assumes no within site variation, which is rarely the case in any ecological study. Therefore, vegetation attributes recorded from all quadrats within a particular community or community type will be used to characterize each habitat type as described by Ratliff and Westfall (1989) and Uresk (1990). The technique allows the classification and ordination of species, quadrats and communities. The approach involves classifying all quadrats into distinct clusters which best represents the ecological continuum of the community. For convenience, the clusters will be designated as low-seral, mid-seral, lateseral and climax. Each site may then be characterized by the percentage of quadrats that are classified into each cluster. For example, it would be expected that relict or near-relict sites would by characterized by a high percentage of climax quadrats and a low percentage of low-seral quadrats. In contrast, a heavily disturbed site may have a low percentage of climax quadrats and a high percentage of low-seral quadrats. Any changes in the community can then be detected by evaluating the differences in the relative proportion of quadrats assigned to each cluster.

Similarity indices (Mueller-Dombois and Ellenberg 1974) will be calculated to objectively compare vegetation among the 143 sites sampled during the 1990 field season. Sorensen's index will be calculated to provide a qualitative measure of similarity, while Ellenberg's Community Coefficient will be calculated to provide a quantitative measure of similarity among the sites. Sorensen's index gives equal weight to the presence or absence of all species recorded at each site while Ellenberg's coefficient is weighted toward the more abundant species (MuellerDombois and Ellenberg 1974). A comparison of the two may provide an indication of the relative contribution of both rare and abundant species. A diversity profile will also be constructed for each habitat type as described by Swindel et al. (1987) and Lewis et al. (1988). Diversity profiles provide an index free method of graphically illustrating the intrinsic diversity between two communities. Results of these analyses will be included in the 1991 annual report.

\section{$\downarrow \quad$ Literature Cited}

Brown, R.W. 1971. Distribution of plant communities in southwestern Montana Badlands. Am. Midl. Nat. 85:331-340.

Butler, J.L., H. Goetz, and J.L. Richardson. 1986. Vegetation and soil-landscape relationships in the North Dakota Badlands. Am. Midl. Nat. 116:378386.

Daubenmire, R. 1959. A canopy-coverage method of vegetation analysis. Northwest Sci. 33:43-66. 
Hansen, P.L., G.R. Hoffman, and A.J. Bjugstad. 1984. The vegetation of Theodore Roosevelt National Park, North Dakota: A habitat type classification. U.S.D.A. Forest Service Gen. Tech. Rep. RM-113. $35 \mathrm{p}$.

Hoffman, G.R. 1989. Vegetation distribution in Badlands National Park. 1989 UW-NPS Research Center Annual Report, Laramie. 9p.

Mueller, Dombois, D., and H. Ellenberg. 1974. Aims and methods of vegetation ecology. J. Wiley, New York.

Lewis, C.E., B.G. Swindel, and G.W. Tenner. 1988. Species diversity and diversity profiles: Concept, measurement, and application to timber and range management. J. Range. Manage. 41:466-469
Olson, V.A. 1988. The steppe vegetation of the North Unit of Badlands National Park. M.S. Thesis, University of South Dakota. 202p.

Ratliff, R.D. and S.E. Westfall. 1989. Monitoring plant community change: an application of quadrat classification and discriminant analysis. Vegetatio 80:1-9.

Swindel, B.F., L.F. Conde, and J.E. Smith. 1987. Index-free diversity orderings. For Ecol. Manage. 8:11-12.

Uresk, D.W. 1990. Using multivariate techniques to quantitively estimate ecological stages in a mixed grass prairie. J. Range Manage. 43:282-285. 